\title{
Pengaruh Pelatihan dan Pengembangan SDM Pada ABA Collection Terhadap Kinerja Pegawai Menggunakan Metode Regresi Linear Berganda
}

\author{
Nadiah Ratnaduhita" ${ }^{* 1)}$, Rio Armando ${ }^{2)}$, Salsabila Qatrunnada ${ }^{3)}$, Tanang Satriyo Adi ${ }^{4)}$, \\ Tanfirul Roibafi ${ }^{5)}$, Wan Azizah Sri Nuraini ${ }^{6}$, dan Ully Asfari ${ }^{7)}$ \\ ${ }^{1)}$ Sistem Informasi, Fakultas Teknologi Informasi dan Industri, Institut Teknologi Telkom Surabaya, \\ Jl. Ketintang No. 156, Ketintang, Kec. Gayungan, Surabaya, 60231, Indonesia \\ Email: nadiahratna@student.ittelkom-sby.ac.id ${ }^{1)}$, rio.armando.19@student.is.ittelkom-sby.ac.id ${ }^{2}$, \\ salsabila.qatrunnada.18@student.is.ittelkom-sby.ac.id ${ }^{33}$, tanang.satriyo.18@student.is.ittelkom-sby.ac.id ${ }^{4)}$, \\ tanfirul.roibafi.18@student.is.ittelkom-sby.ac.id ${ }^{5)}$, wan.azizah.18@ student.is.ittelkom-sby.ac.id ${ }^{6}$, \\ ully.asfari@ittelkom-sby.ac.id ${ }^{7)}$
}

\begin{abstract}
Abstrak
ABA Collection merupakan bisnis konveksi yang memproduksi berbagai macam pakaian dan memiliki beberapa pegawai yang terbagi menjadi beberapa divisi. Tidak ada persyaratan atau ketentuan khusus dalam penerimaan pegawai, dan setiap pegawai mendapatkan pelatihan serta pembinaan agar memiliki keterampilan yang sesuai dengan kebutuhan perusahaan. Penelitian ini bertujuan untuk menganalisis tingkat kepuasan pegawai terhadap pelatihan yang dilaksanakan oleh perusahaan dengan menggunakan metode Regresi Linear Berganda. Hasil penelitian menunjukkan bahwa pelatihan yang telah dilaksanakan terbukti meningkatkan keterampilan pegawai sesuai dengan kebutuhan perusahaan. Berdasarkan hasil yang didapatkan, dapat disimpulkan bahwa pelaksanaan pelatihan dan pembinaan tidak hanya berpengaruh terhadap peningkatan efisiensi dan efektivitas kerja pegawai, namun juga dapat memberikan manfaat dalam meningkatkan semangat kerja para pegawai.
\end{abstract}

Kata kunci: Pelatihan, Tingkat Kepuasan Pegawai, Regresi Linear Berganda

\section{Pendahuluan (Introduction)}

Pada era globalisasi saat ini persaingan dalam dunia usaha semakin ketat, termasuk dalam bidang usaha konveksi. Persaingan yang semakin ketat tersebut menjadi tantangan tersendiri dalam pengembangan usaha konveksi terutama dalam meningkatkan kualitas sumber daya manusia agar memiliki keahlian khusus dalam bidangnya dan mampu bersaing dengan organisasi lainnya. Sumber daya manusia adalah salah satu faktor terpenting dalam keberhasilan organisasi (Lolowang \& Lumintang, 2016). Walaupun saat ini terdapat banyak teknologi mutakhir yang bisa mendukung industri dalam melaksanakan operasionalnya, tetapi industri juga wajib didukung oleh keahlian sumber daya manusia yang profesional, karena secanggih apapun teknologi yang dipergunakan jika tidak didukung oleh karyawan yang profesional belum pasti dapat menjamin kelancaran operasional industri. Sumber daya manusia yang diartikan merupakan karyawan yang terdapat dalam industri, sebab karyawan menjadi suatu SDM yang utama dalam mendukung kelancaran aktivitas industri (Wicaksono, 2016). Sebaliknya sumber daya manusia menjadi salah satu aspek yang sangat berarti dalam suatu industri di samping aspek yang lain semacam modal, oleh sebab itu SDM wajib dikelola dengan baik agar daya guna serta efisiensi organisasi dapat meningkat (Hariandja, 2007).

Suatu organisasi harus mampu menyiapkan strategi agar kualitas sumber daya manusia dapat meningkat, dalam perihal ini kedudukan manajemen sumber daya manusia begitu dibutuhkan. Untuk membangun SDM yang profesional demi terwujudnya tujuan organisasi maka suatu organisasi harus 
dapat memberikan suatu wadah bagi sumber daya yang dimiliki untuk mengembangkan keahlian yang dimiliki. Kinerja karyawan pada organisasi menentukan sukses tidaknya suatu organisasi. Apabila suatu industri membutuhkan keunggulan melalui (SDM), hal ini menjadi wajib bagi industri untuk memberikan pelatihan dan pengembangan SDM secara berkelanjutan agar karyawan dan organisasi lebih efektif (Devi \& Shaik, 2012). Pada penelitian sebelumnya dijelaskan bahwa pengembangan dan pelatihan SDM berpengaruh positif kepada kinerja karyawan, oleh karena itu dengan memberikan wadah berupa pengembangan dan pelatihan SDM diyakini dapat membantu dalam hal peningkatan kinerja karyawan sehingga apa yang menjadi tujuan organisasi bisa terwujud (Mangkunegara \& Waris, 2015).

Pengembangan dan pelatihan SDM menjadi suatu strategi agar terjadi kesesuaian antara pekerjaan dan tugas dengan keterampilan, kemampuan, dan juga keahlian dari masing-masing karyawan. Selain itu hal ini juga menjadi usaha dalam meningkatkan semangat kerja karyawan dalam menjalankan suatu pekerjaan. Setiap industri wajib merancang suatu pelatihan agar sesuai tujuan organisasi dan individu pekerja sehingga pelatihan yang diberikan bisa menciptakan pekerja yang produktif dan terampil. Pelatihan berhubungan dengan rencana untuk menguasai pengetahuan, keterampilan, dan sikap pegawai industri (Suwatno \& Priansa, 2011:118). Pelatihan untuk pegawai merupakan suatu bentuk pengajaran pengetahuan serta keahlian agar terciptanya karyawan yang terampil dan mampu bertanggung jawab atas pekerjaannya sesuai standardisasi perusahaan (Mangkuprawira, 2002:135). Bukan hanya itu, pemberian pelatihan kepada karyawan juga bertujuan agar terwujudnya peningkatan terhadap kemampuan teknis, konseptual, teoritis, dan moral karyawan. Dimana hal ini dapat mendukung tercapainya kinerja yang optimal pada karyawan. Ketepatan dalam pelaksanaan pelatihan juga menjadi tolak ukur dalam perbaikan efektivitas kerja karyawan dalam mewujudkan target yang ditetapkan. Selain itu, pelaksanaan pelatihan (training) juga dapat diartikan sebagai usaha dalam mengantisipasi adanya perubahan yang tidak terprediksikan sebelumnya (Bambang \& Koesmono, 2005). Maka dari itu, perusahaan wajib memahami akan kepentingan program pengembangan dan pelatihan dalam usaha meningkatkan kinerja karyawan. Tidak hanya menyelenggarakan pengembangan dan pelatihan, pengelolaan program pelatihan pun juga penting agar mendapatkan banyak manfaat dan pelaksanaan pelatihan menjadi lebih efektif. Hal ini sangat diperlukan sebab peningkatan pengetahuan, kemampuan, dan keterampilan karyawan berpotensi menjadi sumber keunggulan kompetitif bagi perusahaan (Ronald, 2006).

Dalam penelitian ini, peneliti memilih perusahaan konveksi yang bernama ABA Collection. ABA Collection merupakan perusahaan konveksi yang memproduksi beraneka ragam pakaian, mulai dari pakaian anak-anak sampai dewasa, dan juga pria dan wanita. Perusahaan ini memiliki pegawai yang terbagi dalam beberapa divisi. Dalam proses perekrutan pegawai, perusahaan ini tidak menetapkan persyaratan khusus. Sehingga setiap pegawai baru akan diberikan pelatihan dan pengembangan agar keterampilan masing-masing pegawai memenuhi kebutuhan perusahaan. Pengembangan dan pelatihan pegawai pada usaha tersebut diperlukan untuk memperkaya SDM dari sisi kualitas maupun kuantitas. Dengan tujuan agar visi dan misi perusahaan dapat tercapai yang nantinya menjadi keunggulan kompetitif dan menunjang pengembangan usaha perusahaan (Wijaya, 2013). Adanya sistem perekrutan menjadi suatu penentu secara berkala keefektivitasan operasional perusahaan dan karyawannya. Dimana hal ini didasarkan pada standar, sasaran, dan juga kriteria yang sudah ditetapkan pada sebelumnya (Mathis \& Jackson, 2006).

Kualitas kerja pegawai membawa pengaruh terhadap kestabilan perusahaan untuk mewujudkan tujuan yang sudah ditetapkan. Sebab kualitas dan kuantitas yang dicapai seorang pekerja memiliki makna bahwa pegawai berhasil melaksanakan tugas dengan penuh tanggung jawab (Mangkunegara, 2009:67). Tidak lain tujuan dari konsep tersebut adalah ingin menciptakan SDM sebagai sumber keunggulan untuk bersaing. Pengembangan dan pelatihan menjadi strategi yang benar-benar dibutuhkan 
sebagai upaya peningkatan kinerja karyawan dan perusahaan. Maka dari itu, perlu peningkatan anggaran untuk pelatihan setiap tahunnya, hal ini dipercaya menghasilkan keunggulan untuk bersaing (Tjahjono, 2005; Falola, et.al, 2014). Prestasi kinerja pegawai dapat dipengaruhi oleh beberapa faktor. Secara umum, prestasi kinerja benar ditentukan pada motivasi dan kemampuan karyawan (Mangkunegara, 2009:67). Agar dapat terwujudnya kinerja dan kesuksesan kerja dalam rentan yang panjang diperlukan kebijakan perusahaan, selain itu pegawai juga wajib berkemampuan tepat dalam menjalankan pekerjaannya. Untuk mewujudkan kinerja dan keberhasilan kerja karyawan dalam jangka panjang di samping adanya kebijakan perusahaan, karyawan juga harus memiliki kemampuan ataupun kompetensi yang tepat dalam melakukan pekerjaannya. Peningkatan kinerja pegawai secara individu menjadi pendorong kinerja SDM secara menyeluruh (Arifiyah dan Sunaryo (2017, hal. 4)).

\section{Metode Penelitian (Methods)}

Metode yang digunakan pada penelitian kami yaitu metode Regresi Linier Berganda. Metode ini digunakan untuk mengetahui pengaruh variabel independen terhadap variabel dependen dimana variabel pengembangan dan variabel pelatihan SDM terhadap variabel kinerja pada pegawai ABA Collection. Regresi yang memiliki satu variabel dependen dan dua atau lebih variabel independen dinamakan regresi linier berganda (Sugiyono, 2016:192). Tujuan dari regresi linear berganda adalah untuk mengukur sejauh mana pengaruh variabel bebas terhadap variabel terikat pada program pengembangan SDM melalui pelatihan dan pendidikan terhadap kinerja pegawai.

Pada penelitian ini, kami menggunakan jenis data kuantitatif. Dimana data yang kami gunakan berbentuk angka atau yang diangkakan (scoring) (Sugiyono, 2015:23). Data kuantitatif berkecenderungan dapat dianalisis menggunakan cara statistik dan data yang berupa angka atau skor biasanya diperoleh dengan memakai alat pengumpul yang memiliki jawaban berupa rentang skor atau pertanyaan yang memiliki bobot. Alat ukur yang digunakan pada data kuantitatif berupa kuesioner, data yang didapat berupa jawaban dari karyawan mengenai beberapa pertanyaan yang sudah diajukan (Suprapto, 2001:80). Kuesioner menjadi salah satu teknik untuk mengumpulkan data, dimana dapat dilakukan dengan cara mengajukan beberapa pernyataan maupun pertanyaan secara tertulis yang ditujukan kepada responden (Sugiyono, 2007:142). Pada saat dilakukan pengambilan data melalui kuesioner, data diambil dan dikelola menggunakan penghitungan skala likert. Skala ini digunakan dalam mengukur sikap, persepsi, dan pendapat responden terkait fenomena atau objek tertentu (Siregar, 2016:138).

Skala likert memiliki keterkaitan yang erat dengan data kualitatatif. Skala likert ini memakai beberapa macam pertanyaan dalam mengukur perilaku setiap individu. Dimana setiap individu ini akan merespon dengan memberi penilaian pada setiap butir pernyataan atau pertanyaan yang diberikan, 5 penilaian ini mencakup 5=sangat setuju, $4=$ setuju, $3=$ tidak memutuskan/netral, $2=$ tidak setuju, dan $1=$ sangat tidak setuju. Penggunaan skala likert 5 point ini memberikan pilihan atau kesempatan kepada responden untuk netral.

Pengumpulan data yang telah diambil berdasarkan sumber yaitu terdapat sumber primer dan sumber sekunder (Sugiyono, 2018:213). Sumber primer diambil pada data yang diambil yang telah diperoleh melalui pengamatan, kuesioner, dan wawancara (Sani, 2010:191) terhadap seseorang yang baru saja terkait pada perusahaan yaitu karyawan baru, sedangkan sumber data sekunder tersebut diperoleh namun tidak diambil secara langsung melalui media yang terkait terhadap perusahaan atau pihak lain (Indriantoro, 1999). Sumber data yang diambil pada penelitian ini diambil dengan sumber primer yang berarti menggunakan media kuesioner yang diberikan kepada karyawan ABA Collection, sedangkan untuk sumber data sekunder yang digunakan dalam penelitian ini berupa pengumpulan data dan informasi dengan membaca beberapa jurnal, artikel, ataupun tesis pada penelitian sebelumnya. 
Kemudian dari hasil yang diperoleh data kuesioner akan dilakukan analisis secara kualitatif dan dikuantitatifkan. Yang berguna untuk mengetahui pengaruh sistem pada pelatihan dan pengembangan karyawan terhadap kinerja karyawan.

Dalam penelitian ini mengambil suatu kuesioner berdasarkan populasi yang ada di Perusahaan ABA Collection. Populasi merupakan suatu sumber data yang terdapat karakteristik tertentu pada penelitian yang objek penelitian meliputi manusia, benda-benda, hewan, tumbuh-tumbuhan, atau peristiwa-peristiwa. (Margono, 2010:118). Berdasarkan ciri-ciri yang dijelaskan populasi merupakan sekelompok individu atau objek pengamatan yang terdapat karakteristik tertentu yang diterapkan oleh peneliti untuk dipelajari dan kemudian ditarik kesimpulannya (Suharsimi, 2002). Populasi dan sampel yang telah diambil pada karyawan baru ABA Collection yang sudah melakukan pelatihan dan pembinaan sebelumnya. Sampel sendiri merupakan bagian atau kesimpulan dari populasi yang telah diteliti dan mewakili keseluruhan pada populasi (Arikunto, 2010:174).

Dalam menggunakan metode regresi linear berganda untuk mempermudah perhitungan maka akan dikelola menggunakan suatu software Statistical Product and Service Solution (SPSS). SPSS (Statistical Product and Service Solution) merupakan suatu aplikasi yang digunakan pada sebuah device yang fungsinya digunakan dalam perhitungan statistik (Jonathan Sarwono, 2006:1). Pengolahan data pada aplikasi SPSS ini dapat digunakan sesuai modul-modul yang sudah ditentukan, diantaranya adalah data editor, viewer, high-resolution graphics, database access, data transformations, dengan database relational, analisis distribusi, multiple session, mapping, visualization, dan lain-lain (Zein et al., 2019). Pengolahan data dengan aplikasi SPSS menghasilkan luaran berupa nilai normalitas, korelasi, linearitas, regresi linear berganda.

\section{Hasil dan Pembahasan (Results and Discussions)}

\subsection{Deskripsi Data}

Penyajian data yang telah diperoleh dari masing-masing variabel menggunakan metode kuesioner yang sudah diisi oleh karyawan ABA Collection. Di mana variabel independen (X1) merupakan pelatihan sumber daya manusia sedangkan variabel independen (X2) merupakan pengembangan sumber daya manusia. dan yang terakhir adalah Variabel dependen (Y) merupakan kinerja karyawan. Adapun data dari ketiga variabel adalah sebagai berikut:

Tabel 1. Penyajian Data Variabel

\begin{tabular}{|c|c|c|}
\hline $\begin{array}{l}\text { Pelatihan Sumber } \\
\text { Daya Manusia (X1) }\end{array}$ & $\begin{array}{l}\text { Pengembangan } \\
\text { Daya Manusia (X2) }\end{array}$ & Sumber Kinerja Pegawai (Y) \\
\hline 37 & 37 & 40 \\
\hline 33 & 32 & 32 \\
\hline 33 & 32 & 34 \\
\hline 33 & 33 & 32 \\
\hline 36 & 34 & 31 \\
\hline 34 & 37 & 34 \\
\hline 32 & 35 & 27 \\
\hline 32 & 34 & 35 \\
\hline 32 & 32 & 32 \\
\hline 35 & 40 & 37 \\
\hline 40 & 40 & 40 \\
\hline
\end{tabular}




\begin{tabular}{|c|c|c|}
\hline 31 & 34 & 31 \\
\hline 37 & 37 & 33 \\
\hline 40 & 40 & 40 \\
\hline 32 & 32 & 33 \\
\hline 34 & 33 & 33 \\
\hline 33 & 31 & 31 \\
\hline 32 & 32 & 32 \\
\hline 37 & 35 & 35 \\
\hline 31 & 30 & 30 \\
\hline 33 & 32 & 32 \\
\hline 36 & 38 & 32 \\
\hline 32 & 32 & 32 \\
\hline 32 & 32 & 32 \\
\hline 38 & 31 & 33 \\
\hline 40 & 40 & 40 \\
\hline 40 & 40 & 40 \\
\hline 40 & 39 & 37 \\
\hline 32 & 32 & 32 \\
\hline 32 & 32 & 31 \\
\hline 30 & 30 & 32 \\
\hline 30 & 32 & 33 \\
\hline 37 & 37 & 35 \\
\hline 30 & 31 & 32 \\
\hline 35 & 35 & 34 \\
\hline 35 & 34 & 36 \\
\hline 31 & 32 & 30 \\
\hline 33 & 34 & 33 \\
\hline 32 & 32 & 32 \\
\hline 36 & 38 & 36 \\
\hline
\end{tabular}

\subsection{Hipotesis Penelitian}

Berikut merupakan hipotesis penelitian yang akan diuji dari oleh peneliti pada penelitian ini:

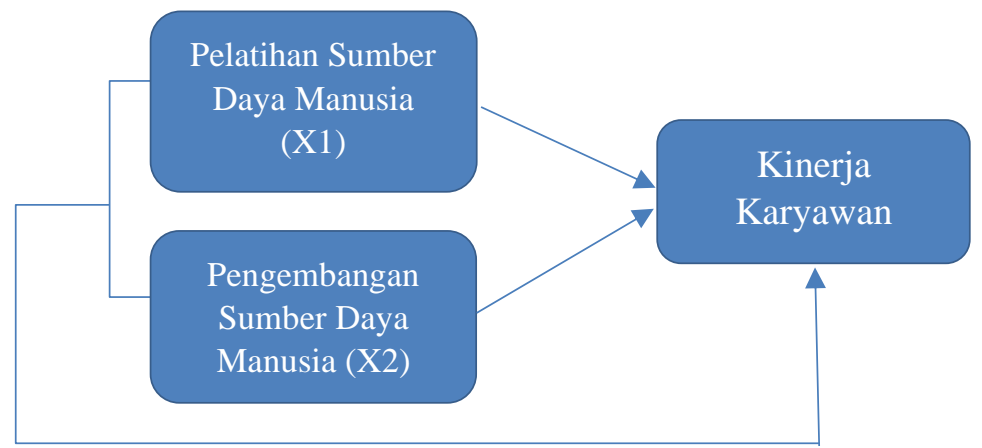

Gambar 1. Hipotesis Penelitian 
H1: Pelatihan dan Pengembangan Sumber Daya Manusia yang dilakukan secara simultan berpengaruh terhadap kinerja karyawan pada ABA Collection Tulungagung.

H2: Pelatihan Sumber Daya Manusia yang dilakukan berpengaruh terhadap kinerja karyawan pada ABA Collection Tulungagung.

H3: Pengembangan Sumber Daya Manusia berpengaruh terhadap kinerja karyawan pada ABA Collection Tulungagung.

\subsection{Uji Asumsi Dasar}

\subsubsection{Uji Normalitas}

Untuk mengetahui apakah data berdistribusi normal, dapat menggunakan uji normalitas. Uji normalitas yang digunakan dalam penelitian ini menggunakan uji ShapiroWilk karena data yang digunakan $<1000$ data dan tingkat signifikansi 0,05 . Jika signifikansi $>0,05$ maka data dinyatakan berdistribusi normal. Hasil uji normalitas SPSS adalah sebagai berikut:

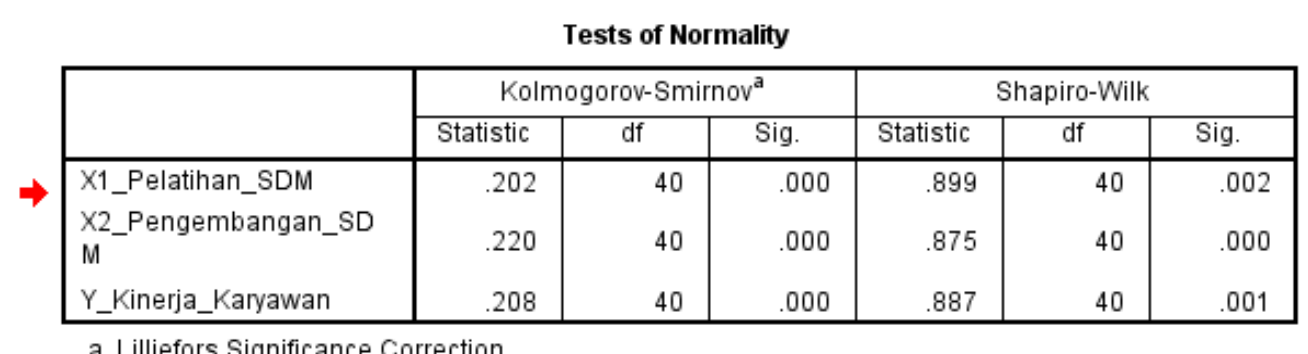

Gambar 2. Uji Normalitas

Dari tabel diatas diperoleh angka signifikansi, nilai tersebut dibandingkan dengan taraf signifikansi 0.05. Dasar pengambilan keputusan pada uji normalitas adalah sebagai berikut:

- Data berdistribusi normal bila nilai signifikansi $>0.05$.

- Data berdistribusi tidak normal bila nilai signifikansi $<0.05$.

Kesimpulan yang dapat diambil dari data di atas adalah bahwa ketiga data tersebut berdistribusi tidak normal, karena dapat dilihat bahwa nilai signifikansi variabel pelatihan sumber daya manusia (X1) adalah 0,002, dimana nilainya $<0,05$. Variabel Pengembangan Sumber Daya Manusia (X2) memiliki nilai signifikansi 0,000 yang berarti $<0,05$ dan nilai signifikansi variabel Kinerja Karyawan (Y) sebesar 0,001 yang berarti $<0,05$.

\subsubsection{Uji Korelasi}

Uji Korelasi dapat digunakan untuk melihat seberapa kuat hubungan yang ada pada kedua variabel atau lebih. Uji korelasi pada penelitian ini menggunakan Uji Spearman dikarenakan data yang telah diambil menghasilkan data berdistribusi tidak normal. Taraf signifikansi yang digunakan adalah 0.05. Hasil dari uji korelasi yang telah dilakukan SPSS sebagai berikut: 


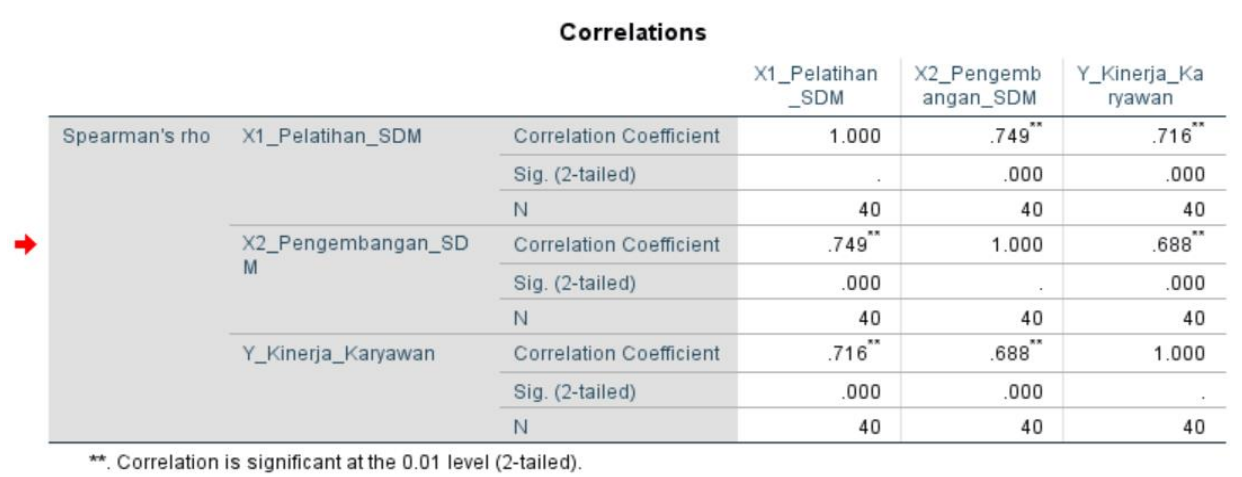

Gambar 3. Uji Korelasi

Dari tabel diatas diperoleh angka signifikansi, nilai tersebut dibandingkan dengan taraf signifikansi 0.05. Dasar pengambilan keputusan pada uji korelasi adalah sebagai berikut:

- Hasil dari Uji tersebut tidak berhubungan secara signifikan antara pelatihan sumber daya manusia (X1), pengembangan sumber daya manusia (X2) dan kinerja karyawan (Y) nilai signifikansi $>0.05$

- Terdapat hubungan yang signifikan pada pelatihan sumber daya manusia (X1), pengembangan sumber daya manusia (X2) dan kinerja karyawan (Y) bila nilai signifikansi $<0.05$

Dari tabel di atas didapatkan dari nilai signifikansi 0.000, di mana nilai $<0.05$ dapat disimpulkan apabila hubungan yang bersifat signifikan antara pelatihan sumber daya manusia (X1), pengembangan sumber daya manusia (X2) dan kinerja karyawan (Y). merupakan hubungan yang telah diperoleh pada hasil pengolahan data tersebut adalah positif, yang dapat diartikan jika semakin tinggi pelatihan sumber daya manusia (X1) dan pengembangan sumber daya manusia (X2) maka semakin tinggi juga kinerja yang diberikan oleh karyawan.

Korelasi antara pelatihan sumber daya manusia (X1) dengan kinerja karyawan (Y) yaitu terdapat tabel dengan tanda bintang dengan angka $0.716^{* *}$, hal tersebut menunjukkan bahwa hubungan tersebut sangatlah kuat pada pelatihan sumber daya manusia (X1) dengan kinerja karyawan (Y). Sedangkan korelasi antara pengembangan sumber daya manusia (X2) dengan kinerja karyawan $(\mathrm{Y})$ adalah $0.688^{* *}$, hal tersebut menunjukkan bahwa hubungan tersebut sangatlah kuat pada pengembangan sumber daya manusia (X2) dengan kinerja karyawan (Y).

\subsubsection{Uji Linearitas}

Uji linearitas merupakan sebuah uji asumsi klasik yang dilakukan untuk mengetahui apakah hubungan kedua variabel memiliki hubungan secara linear atau tidak secara signifikan pada sebaran tersebut antara variabel X dan Y. Dikarenakan sebuah model regresi yang baik terdapat hubungan linear antara variabel. Kami menggunakan uji tersebut dalam penelitian ini berfungsi dalam mengetahui bagaimana hubungan antara variabel independen tersebut dengan pelatihan sumber daya manusia (X1), pengembangan sumber daya manusia (X2), dan variabel dependen kinerja karyawan (Y). Data akan dinyatakan linear apabila memiliki signifikansi deviasi > 0.05. Berikut adalah hasil dari uji linearitas pada SPSS: 
- Pelatihan Sumber Daya Manusia (X1)

\begin{tabular}{|c|c|c|c|c|c|c|c|}
\hline \multicolumn{8}{|c|}{ ANOVA Table } \\
\hline & & & $\begin{array}{l}\text { Sum of } \\
\text { Squares }\end{array}$ & df & Mean Square & $\mathrm{F}$ & Sig. \\
\hline \multirow{5}{*}{$\begin{array}{l}\text { Y_KINERJA_KARYAWAN } \\
\text { "X1_PELATIHAN_SDM }\end{array}$} & \multirow[t]{3}{*}{ Between Groups } & (Combined) & 279.717 & 9 & 31.080 & 9.775 & .000 \\
\hline & & Linearity & 226.061 & 1 & 226.061 & 71.101 & .000 \\
\hline & & Deviation from Linearity & 53.655 & 8 & 6.707 & 2.109 & .066 \\
\hline & Within Groups & & 95.383 & 30 & 3.179 & & \\
\hline & Total & & 375.100 & 39 & & & \\
\hline
\end{tabular}

Gambar 4. Uji Linearitas Variabel X1 dengan Y

- Pengembangan Sumber Daya Manusia (X2)

\begin{tabular}{|c|c|c|c|c|c|c|c|}
\hline \multicolumn{8}{|c|}{ ANOVA Table } \\
\hline & & & $\begin{array}{l}\text { Sum of } \\
\text { Squares }\end{array}$ & df & Mean Square & $\mathrm{F}$ & Sig. \\
\hline \multirow{5}{*}{$\begin{array}{l}\text { Y_KINERJA_KARYAWAN } \\
\text { X2_PENGEMBANGAN_S } \\
\text { DM }\end{array}$} & \multirow[t]{3}{*}{ Between Groups } & (Combined) & 256.677 & 9 & 28.520 & 7.225 & .000 \\
\hline & & Linearity & 216.389 & 1 & 216.389 & 54.818 & .000 \\
\hline & & Deviation from Linearity & 40.288 & 8 & 5.036 & 1.276 & .293 \\
\hline & Within Groups & & 118.423 & 30 & 3.947 & & \\
\hline & Total & & 375.100 & 39 & & & \\
\hline
\end{tabular}

Gambar 5. Uji Linearitas Variabel X2 dengan Y

Berdasarkan tabel Anova di atas, dapat diketahui bahwa hubungan antara variabel pelatihan sumber daya manusia (X1), dan variabel pengembangan sumber daya manusia (X2) dengan variabel kinerja karyawan (Y) adalah linear. Hal tersebut dibuktikan dengan variabel pelatihan sumber daya manusia (X1) yang memiliki nilai signifikansi 0.066 dan variabel pengembangan sumber daya manusia (X2) yang memiliki nilai signifikansi 0.293, di mana kedua nilai signifikansi tersebut $>0.05$.

\subsubsection{Uji Regresi Linear Berganda}

Uji regresi linear berganda merupakan uji yang dilakukan untuk mengetahui seberapa besar persentase variabel independen berpengaruh terhadap variabel dependen dengan menggunakan metode Enter. Data akan dinyatakan berpengaruh apabila memiliki signifikansi $>0.05$. Berikut adalah hasil uji regresi linear berganda pada SPSS:

\begin{tabular}{|c|c|c|c|c|c|}
\hline \multicolumn{6}{|c|}{ Model Summary $^{b}$} \\
\hline Model & $\mathrm{R}$ & R Square & $\begin{array}{c}\text { Adjusted R } \\
\text { Square }\end{array}$ & $\begin{array}{l}\text { Std. Error of } \\
\text { the Estimate }\end{array}$ & $\begin{array}{l}\text { Durbin- } \\
\text { Watson }\end{array}$ \\
\hline 1 & $.806^{\mathrm{a}}$ & .650 & .631 & 1.883 & 2.114 \\
\hline
\end{tabular}

\section{Gambar 6. Model Summary}

Berdasarkan tabel Model Summary di atas, dapat diketahui bahwa nilai R Square adalah 0.650. Dengan begitu dapat dikatakan variabel pelatihan sumber daya manusia (X1), dan variabel pengembangan sumber daya manusia (X2) berpengaruh terhadap variabel kinerja karyawan (Y) dengan persentase $65 \%$, dan variabel lain di luar penelitian ini berpengaruh atas $35 \%$ sisanya. Berikut adalah uji hipotesis dari ketiga variabel tersebut pada SPSS: 




\section{Gambar 7. Uji Anova}

Dari tabel diatas diperoleh angka signifikansi, nilai tersebut akan dibandingkan dengan taraf signifikansi yaitu 0.05. Pengambilan keputusan pada uji hipotesis adalah:

- Jika nilai signifikansi < 0.05 maka variabel pelatihan sumber daya manusia (X1) dan variabel pengembangan sumber daya manusia (X2) berpengaruh terhadap kinerja karyawan (Y)

- Jika nilai signifikansi > 0.05 maka variabel pelatihan sumber daya manusia (X1) dan variabel pengembangan sumber daya manusia (X2) tidak berpengaruh terhadap kinerja karyawan (Y)

Kesimpulan dari data di atas didapatkan nilai signifikansi sebesar 0.000 , dimana nilai tersebut $<0.05$, maka dapat disimpulkan bahwa variabel pelatihan sumber daya manusia (X1) dan variabel pengembangan sumber daya manusia (X2) berpengaruh terhadap kinerja karyawan $(\mathrm{Y})$. Selanjutnya untuk melihat multikolinearitas, model persamaan regresi, dan ada tidaknya pengaruh variabel pelatihan sumber daya manusia dan pengembangan sumber daya manusia terhadap kinerja karyawan ABA Collection adalah sebagai berikut:

\begin{tabular}{|c|c|c|c|c|c|c|c|}
\hline \multicolumn{8}{|c|}{ Coefficients $^{a}$} \\
\hline \multirow[b]{2}{*}{ Model } & \multicolumn{2}{|c|}{ Unstandardized Coefficients } & \multirow{2}{*}{$\begin{array}{c}\begin{array}{c}\text { Standardized } \\
\text { Coefficients }\end{array} \\
\text { Beta } \\
\end{array}$} & \multirow[b]{2}{*}{$\mathrm{t}$} & \multirow[b]{2}{*}{ Sig. } & \multicolumn{2}{|c|}{ Collinearity Statistics } \\
\hline & $B$ & Std. Error & & & & Tolerance & VIF \\
\hline (Constant) & 4.654 & 3.509 & & 1.326 & .193 & & \\
\hline X1_Pelatihan_SDM & .474 & 170 & .468 & 2.785 & .008 & .334 & 2.993 \\
\hline $\begin{array}{l}\text { X2_Pengembangan_SD } \\
M\end{array}$ & & .166 & .377 & 2.242 & .031 & .334 & 2.993 \\
\hline
\end{tabular}

Gambar 8. Coefficients antar Variabel

Untuk mengetahui apakah terdapat multikolinearitas atau tidak adalah dengan membandingkan nilai pada Tolerance dengan 0.1. Apabila nilai Tolerance $>0.1$ berarti tidak terdapat multikolinearitas. Dari tabel diatas didapatkan nilai Tolerance dari kedua variabel bebas adalah 0.334 di mana nilai tersebut $>0.1$ sehingga tidak terdapat multikolinearitas.

Sedangkan untuk mengetahui pengaruh variabel pelatihan sumber daya manusia dan pengembangan sumber daya manusia terhadap kinerja karyawan ABA Collection dapat dilihat dari signifikansi tabel "Coefficients" di atas. Pengambilan keputusan adalah sebagai berikut:

- Jika nilai signifikansi < 0.05 maka terdapat pengaruh antara variabel pelatihan sumber daya manusia (X1) dan variabel pengembangan sumber daya manusia (X2) terhadap kinerja karyawan (Y) atau hipotesis diterima

- Jika nilai signifikansi > 0.05 maka tidak terdapat pengaruh antara variabel pelatihan sumber daya manusia (X1) dan variabel pengembangan sumber daya manusia (X2) terhadap kinerja karyawan (Y) atau hipotesis ditolak.

Berdasarkan data tabel "Coefficients" di atas diketahui nilai signifikansi variabel pelatihan sumber daya manusia (X1) adalah sebesar 0.08 di mana nilai tersebut $>0.05$, sehingga dapat disimpulkan bahwa tidak terdapat pengaruh antara variabel pelatihan sumber 
daya manusia (X1) terhadap kinerja karyawan (Y) atau hipotesis ditolak. Sedangkan nilai signifikansi variabel pengembangan sumber daya manusia (X2) adalah 0.31 sehingga terdapat pengaruh antara variabel pengembangan sumber daya manusia (X2) terhadap kinerja karyawan (Y) atau hipotesis diterima.

Dari tabel "Coefficients" tersebut didapatkan model persamaan regresi sebagai berikut:

$$
Y=4.654+0.372 X 2
$$

Dalam persamaan regresi linear tersebut, variabel pelatihan sumber daya manusia (X1) tidak dituliskan karena tidak terdapat pengaruh antara variabel pelatihan sumber daya manusia (X1) terhadap kinerja karyawan (Y) atau hipotesis ditolak.

Nilai konstanta sebesar 4.654 pada persamaan di atas menunjukkan besarnya kinerja karyawan $(\mathrm{Y})$ yang tidak dipengaruhi oleh variabel pengembangan sumber daya manusia (X2). Hal itu berarti jika pengembangan sumber daya manusia $(\mathrm{X} 2)=0$, maka kinerja karyawan $(\mathrm{Y})$ sebesar 4.654. Angka tersebut menunjukkan adanya faktor lain selain variabel X2 yang mempengaruhi kinerja karyawan pada ABA Collection.

Dari nilai koefisien regresi diketahui bahwa pengembangan sumber daya manusia (X2) $=0.372$, dari angka tersebut berarti terdapat arah pengaruh yang positif antara pengembangan sumber daya manusia (X2) terhadap kinerja karyawan (Y). Kinerja karyawan akan meningkat sebesar 0.372 atau $37.2 \%$ jika variabel pengembangan sumber daya manusia (X2) ditingkatkan sebesar satu satuan.

\section{Kesimpulan (Conclusion)}

Dari hasil data penelitian yang telah diuji pada software SPSS dapat disimpulkan bahwa pengembangan sumber daya manusia pada ABA Collection berpengaruh terhadap kinerja pegawai. Hubungan yang terbentuk dari ketiga variabel adalah positif, yang berarti apabila pengembangan sumber daya manusia diperbaiki maka kinerja pegawai juga akan lebih baik. Model yang didapatkan dari pengujian dengan variabel independen yaitu pelatihan sumber daya manusia (X1), pengembangan sumber daya manusia (X2), dan variabel dependen yaitu kinerja pegawai (Y) adalah sebagai berikut:

$$
\mathrm{Y}=\mathbf{4 . 6 5 4}+\mathbf{0 . 3 7 2 X 2}
$$

Koefisien regresi dari data tersebut adalah 4.654, angka tersebut menunjukkan adanya faktor lain selain variabel X2 yang mempengaruhi kinerja karyawan pada ABA Collection. Nilai positif dari koefisien regresi menggambarkan bahwa arah hubungan antara variabel pengembangan sumber daya manusia (X2) dan kinerja karyawan (Y) adalah positif atau searah, sehingga kinerja karyawan akan meningkat sebesar 0.372 atau $37.2 \%$ jika variabel pengembangan sumber daya manusia (X2) ditingkatkan sebesar satu satuan.

\section{Ucapan Terima Kasih (Acknowledgement)}

Dalam penyelesaian penyusunan penelitian ini, penulis mendapat banyak bantuan dari beberapa pihak yang terlibat. Maka dari itu ucapan terima kasih yang sebesar-besarnya penulis sampaikan kepada Ibu Ully Asfari, S.Kom., M.Kom. selaku dosen yang membimbing penelitian ini, seluruh atasan dan karyawan ABA Collection, serta seluruh pihak yang telah berkontribusi dalam penelitian pengaruh pelatihan dan pengembangan sumber daya manusia pada ABA Collection terhadap kinerja pegawai sehingga dapat dituangkan dalam bentuk tulisan. 


\section{Daftar Pustaka}

Agusta, L. \& Sutanto, E. M., 2013. Pengaruh Pelatihan dan Motivasi Kerja Terhadap Kinerja Karyawan CV Haragon Surabaya. AGORA, Volume 1.

Al Qudah, H. M., 2014. The Effect Of Human Resource Management Practices On Employee Performance. International Journal of Scientific \& Technology Research, 3(9).

Bisono, G. A., 2016. Pengaruh Sistem Pelatihan dan Pengembangan Karyawan Terhadap Kinerja Karyawan PT. Persada Sawit Mas (PSM) Kecamatan Pampangan Kabupaten Ogan Komering Ilir. Volume 1.

Heryana, D., Setiawati, L. \& Suhendar, B., 2019. Sistem Informasi dan Potensi Manfaat Big Data Untuk Pendidikan. Jurnal Kehumasan, Volume 2.

Lolowang, M. G., Adolfina \& Lumintang, G., 2016. PENGARUH PELATIHAN DAN PENGEMBANGAN SUMBER DAYA MANUSIA TERHADAP KINERJA KARYAWAN PADA PT. BERLIAN KHARISMA PASIFIK MANADO. JURNAL EMBA: JURNAL RISET EKONOMI, MANAJEMEN, BISNIS DAN AKUNTANSI.

Mangkunegara, A. P. \& Waris, A., 2015. Effect of Training, Competence and Discipline on Employee Performance in Company (Case Study in PT. Asuransi Bangun Askrida). Procedia - Social and Behavioral Sciences, Volume 211, pp. 1240-1251.

Mua'rrifa, Z. I., Rustono \& Wahyuni, S., n.d. Pengaruh Pelatihan dan Motivasi Karyawan Terhadap Kepuasan Kerja Karyawan pada PT. Pelabuhan Indonesia III (Persero) Cabang Tanjung Emas Semarang.

Roswaty \& Siddiq, A. M., n.d. Analisis Pengaruh Pelatihan dan Pengembangan Sumber Daya Manusia Terhadap Kinerja Pegawai pada Dinas Pemberdayaan Perempuan dan Perlindungan Anak Kabupaten Musi Banyuasin Sumatera Selatan. Volume 10.

Sulaefi, 2017. PENGARUH PELATIHAN DAN PENGEMBANGAN. Jurnal Manajemen \& Kewirausahaan, Volume 5.

Suryoadi, Y., 2011. Pengaruh Pelatihan dan Kepuasan Kompensasi Terhadap Kinerja Karyawan pada PT. Bank Muamalat Indonesia Cabang Semarang.

Sutisna, I., 2020. Teknik Analisis Data Penelitian Kuantitatif.

Tampi, B. J., 2014. Pengaruh Gaya Kepemimpinan dan Motivasi Terhadap Kinerja Karyawan Pada PT. Bank Negara Indonesia, Tbk (Regional Sales Manado). Acta Diurna, Volume 3.

Wasisto, J., 2014. Pengaruh Metode Pelatihan Terhadap Kemampuan dan Kinerja Pegawai (Studi pada Pegawai Struktural Balai Besar Pelatihan (BBPP) Ketindan-Lawang). Jurnal Administrasi Bisnis, Volume 12.

Wicaksono, Y. S., 2016. Pengaruh Pelatihan dan Pengembangan Sumber Daya Manusia Dalam Rangka Meningkatkan Semangat Kerja dan Kinerja Karyawan (Studi di SKM Unit V PT. Gudang Garam, Tbk Kediri). Jurnal Bisnis dan Manajemen, Volume 3.

Wijaya, W., 2013. Analisis Pelatihan dan Pengembangan Sumber Daya Manusia Pada Pabrik Kecap Wie Sin di Lombok1. AGORA, Volume 1. 
Wulansari, P. W., 2017. Analisis Pengaruh Pelatihan SDM dan Motivasi Kerja Terhadap Kinerja Karyawan Divisi Operasional (Studi Kasus : Pada PT. Bank Capital Indonesia).

Zein, S. et al., 2019. Pengolahan dan Analisis Data Kuantitatif Menggunakan Aplikasi SPSS. Jurnal Teknologi Pendidikan dan Pembelajaran, Volume 4. 